\title{
Rare insights
}

Madagascar's biodiversity is unique and imperilled. Separated from the mainland of Africa for 160 million years, the island is home to thousands of species found nowhere else, as detailed in The Natural History of Madagascar, a paperback edition of which was published in March (University of Chicago Press, \$50). This hefty desk reference features expert contributions covering the history of scientific exploration in Madagascar, its geology, climate, ecology and conservation, as well as its plants, invertebrates, fishes, amphibians, reptiles, birds and mammals. The book also includes over four hundred illustrations and photos - including this one of a lowland streaked tenrec (Hemicentetes semispinosus), found in the forest of Andrambovato in the south east of the island. These small, insecteating mammals live together in burrows and make subsonic calls by rustling their spines; like many Malagasy species they are losing habitat to deforestation.

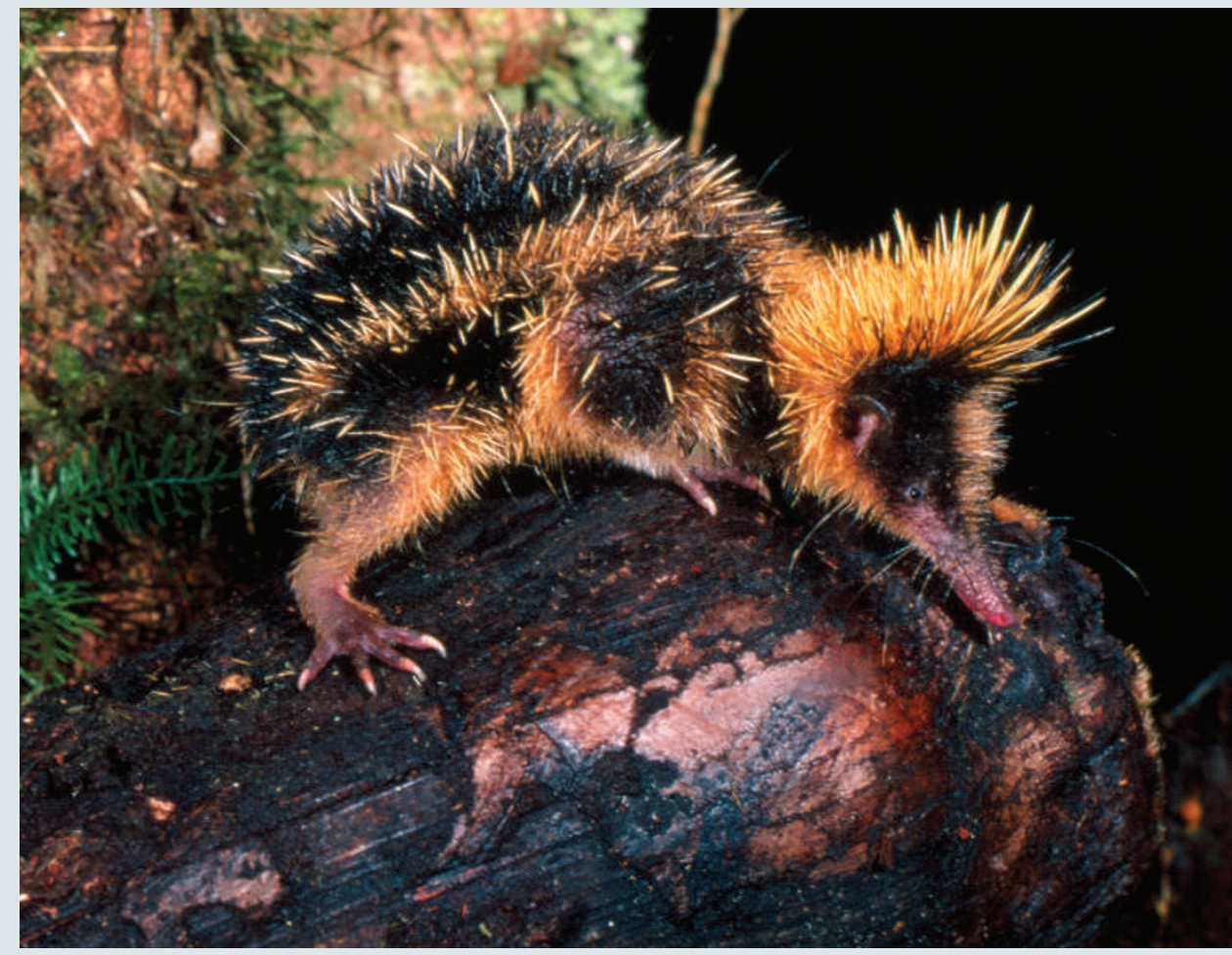

\section{Cancer case histories}

\section{The Cancer Treatment Revolution David G Nathan Wiley: 2007. 272 pp. \$24.95, £16.99}

\section{Karol Sikora}

Using the histories of three of his patients, David Nathan tells the remarkable, sometimes frustrating, story of the development of modern cancer drugs. The Cancer Treatment Revolution is extremely well written by this retired, leading figure in the US cancer scene, who has contributed greatly to the scientific and clinical research.

Its detailed account of the history of chemotherapy is fascinating, even if it does suggest that everything was done in Boston. It is so difficult to imagine how the early human experiments could ever have been carried out in today's ethical climate. Pumping little children full of horrible drugs to obtain just a few weeks survival benefit is no fun for any doctor. But without those pioneers and the suffering children, we would not have the drugs for cancer we routinely use today.

The book gives a very readable account of the discovery and clinical development of molecularly targeted therapies over the past ten years. This has been a major triumph for the rational application of molecular biology to one of the greatest unmet medical needs of our time. We now seem to be at the beginning of a revolution - moving on from cancer treatment that blasts away malignant cells using toxic chemicals to cause widespread havoc to the patient's physiology, towards a more specific and gentler, patient-tailored approach. Converting cancer into a chronic, controllable illness now seems to be a distinct possibility. But we're not quite there yet.

The tensions between the medical community, the research funders and institutes, the US Food and Drug Administration, the pharmaceutical industry and the taxpayers have dramatically increased and are well outlined by Nathan. He clearly doesn't like the politics - stating "science policy in the Bush administration can only be described as absurd and dangerous". Wonderful stuff — in some countries he could find himself without a job, in others in jail for treason and in a few just disappear. But I'm sure most readers would like some elaboration. Nonetheless, there is no doubt that the United States has committed huge amounts of money to the war on cancer. Whether it has been a worthwhile quest remains to be seen but, as Nathan points out, it has heavily subsidized the entire biomedical research endeavour.

The biggest difficulty with this book is working out exactly who it is written for. Most patients and their carers would find it scientifically too demanding. Even with its glossary, the vocabulary is more for a Nature subscriber than a newspaper reader. Most of it would be simply irrelevant to any individual with cancer - of the three detailed case histories covered, two are about extremely rare conditions (gastrointestinal stromal tumour and mixedlineage leukaemia). The emotional content all seems a little hollow - almost as though it's been added as an afterthought. Doctors on the whole shudder when they see a chapter headed "Ken's story". We tend to try to box off the human side of disease so we can get on with the business in hand: doing the best we can to cure or prolong life. When we read about the science of cancer we want it unbundled from the fear, concern and hope. There are plenty of excellent psychosocial texts around. And patients prefer a much more user-friendly and less technical communication style tailored to their precise clinical problem. There are some excellent examples of this genre from various cancer charities on both sides of the Atlantic as well as Adam Wishart's One in Three (Profile Books, 2006) or Rosy Daniel's "Cancer Lifeline Kit” (www.healthcreation.co.uk/kit.htm).

Maybe senior academic physicians should stick to writing about the science of cancer treatment and get others to do the popularization. Currently, the alternative medicine movement dominates the bookstore shelves on cancer. Wacky diets, bizarre relaxation exercises, crank healers and of course herbal remedies all promise a cure without any side effects. These texts are inspirational, conclusive and positive. In an era of patient choice, that seems to be what the customers really want. So while I enjoyed and learned a lot from this great account of the wonderful achievements of science and medicine, I feel it is unlikely to be a bestseller at the airport.

Karol Sikora is the Medical Director of Cancer-

PartnersUK, 21 Barrett Street, London W1U 1BD. 